\title{
A community cluster of influenza A(H1N1)pdm09 virus exhibiting cross-resistance to oseltamivir and peramivir in Japan, November to December 2013
}

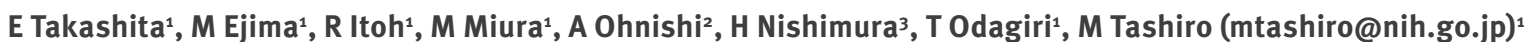

1. Influenza Virus Research Center, National Institute of Infectious Diseases, Tokyo, Japan

2. Sapporo City Institute of Public Health, Hokkaido, Japan

3. Virus Research Center, Sendai Medical Center, Miyagi, Japan

Citation style for this article:

Takashita E, Ejima M, Itoh R, Miura M, Ohnishi A, Nishimura H, Odagiri T, Tashiro M. A community cluster of influenza A(H1N1)pdmog virus exhibiting cross-

resistance to oseltamivir and peramivir in Japan, November to December 2013. Euro Surveill. 2014;19(1):pii=20666. Available online: http://www.eurosurveillance. org/ViewArticle.aspx?Articleld $=20666$

Article submitted on 30 December 2013 / published on 09 January 2014

Six influenza $A\left(\mathrm{H}_{1} \mathrm{~N}_{1}\right)$ pdmog viruses were detected in Sapporo, Japan, between November and December 2013. All six viruses possessed an $\mathrm{H}_{275} \mathrm{Y}$ substitution in the neuraminidase protein, which confers crossresistance to oseltamivir and peramivir. No epidemiological link among the six cases could be identified; none of them had received neuraminidase inhibitors before specimen collection. The haemagglutinin and neuraminidase genes of the six viruses were closely related to one another, suggesting clonal spread of a single resistant virus.

\section{Detection of mutant $\mathrm{H} 275 \mathrm{Y}$ influenza $A(H 1 N 1) p d m 09$ viruses}

Between September and December 2013, 76 influenza $A\left(H_{1} N_{1}\right) p d m 09$ viruses were detected in 20 local public health institutes in Japan and then screened by allelic discrimination [1] and/or neuraminidase (NA) gene sequencing to detect an $\mathrm{H}_{275} \mathrm{Y}$ substitution, which confers resistance to oseltamivir and peramivir [2] (Figure 1). This is part of our nationwide monitoring for antiviral-resistant influenza viruses in cooperation with 74 local public health institutes [2]: such surveillance is important for public health planning and clinical recommendations for antiviral use. We found that seven of the 76 influenza $A\left(\mathrm{H}_{1} \mathrm{~N}_{1}\right)$ pdmog viruses possessed the $\mathrm{H}_{275} \mathrm{Y}$ substitution. Six of the seven $\mathrm{H} 275 \mathrm{Y}$ mutant viruses were detected in Sapporo, the capital city of Hokkaido, the second-largest island in Japan. The seventh case was detected from another part of the country. In Sapporo, six influenza $A\left(\mathrm{H}_{1} \mathrm{~N}_{1}\right)$ pdmog viruses were detected during weeks $46-50$, and all six viruses possessed the $\mathrm{H}_{275} \mathrm{Y}$ substitution. Elsewhere in Hokkaido, nine influenza viruses were detected: all were influenza $A\left(\mathrm{H}_{3} \mathrm{~N}_{2}\right)$ viruses. In this article, we focus on the analysis of the six $\mathrm{H}_{275} \mathrm{Y}$ mutant viruses detected in Sapporo.

Isolate details from the six cases in Sapporo are shown in Table 1. Clinical specimens of the patients were collected in three paediatric clinics (serving outpatients only) and two general hospitals (serving outpatients and inpatients). Five of the six patients were male and four were children (aged up to 10 years). Five male patients showed mild symptoms and received only outpatient care, but a woman in her late 30 s without underlying disease was hospitalised for severe pneumonia. She was admitted to an intensive-care unit because of acute respiratory distress syndrome and is currently in critical condition. All six cases occurred sporadically and no epidemiological link among them could be identified. None of them had received NA inhibitors before specimen collection. The nucleotide sequences of the haemagglutinin (HA) and NA genes of the six viruses were closely related to one another (Figure 2). These results suggest the clonal spread of a single $\mathrm{H}_{275} \mathrm{Y}$ mutant virus in Sapporo.

\section{Antiviral susceptibility of H275Y mutant viruses}

We analysed the susceptibility of five of the six $\mathrm{H} 275 \mathrm{Y}$ mutant viruses detected in Sapporo to four NA inhibitors approved in Japan: oseltamivir, peramivir, zanamivir and laninamivir (Table 2); the sixth virus could not be cultured. A/Perth/261/2009 and A/Perth/265/2009 [3] were used as reference $\mathrm{H}_{275} \mathrm{Y}$ mutant and $275 \mathrm{H}$ wildtype $\mathrm{A}\left(\mathrm{H}_{1} \mathrm{~N}_{1}\right)$ pdmog viruses, respectively. Oseltamivir carboxylate, peramivir and zanamivir were purchased from Sequoia Research Products (Pangbourne, United Kingdom) and laninamivir was kindly provided by Daiichi Sankyo Co., Ltd. (Tokyo, Japan). The susceptibility of these viruses to NA inhibitors was determined by fluorescent enzyme inhibition assay with the NA-Fluor Influenza Neuraminidase Assay Kit (Applied Biosystems, California, United States). Results were expressed as the drug concentrations required to inhibit NA activity by $50 \%\left(\mathrm{IC}_{50}\right)$. The $\mathrm{IC}_{50}$ values were calculated using MikroWin 2000 software (Mikrotek Laborsysteme $\mathrm{GmbH}$, Overath, Germany). To interpret the NA inhibitor susceptibility, the World Health 


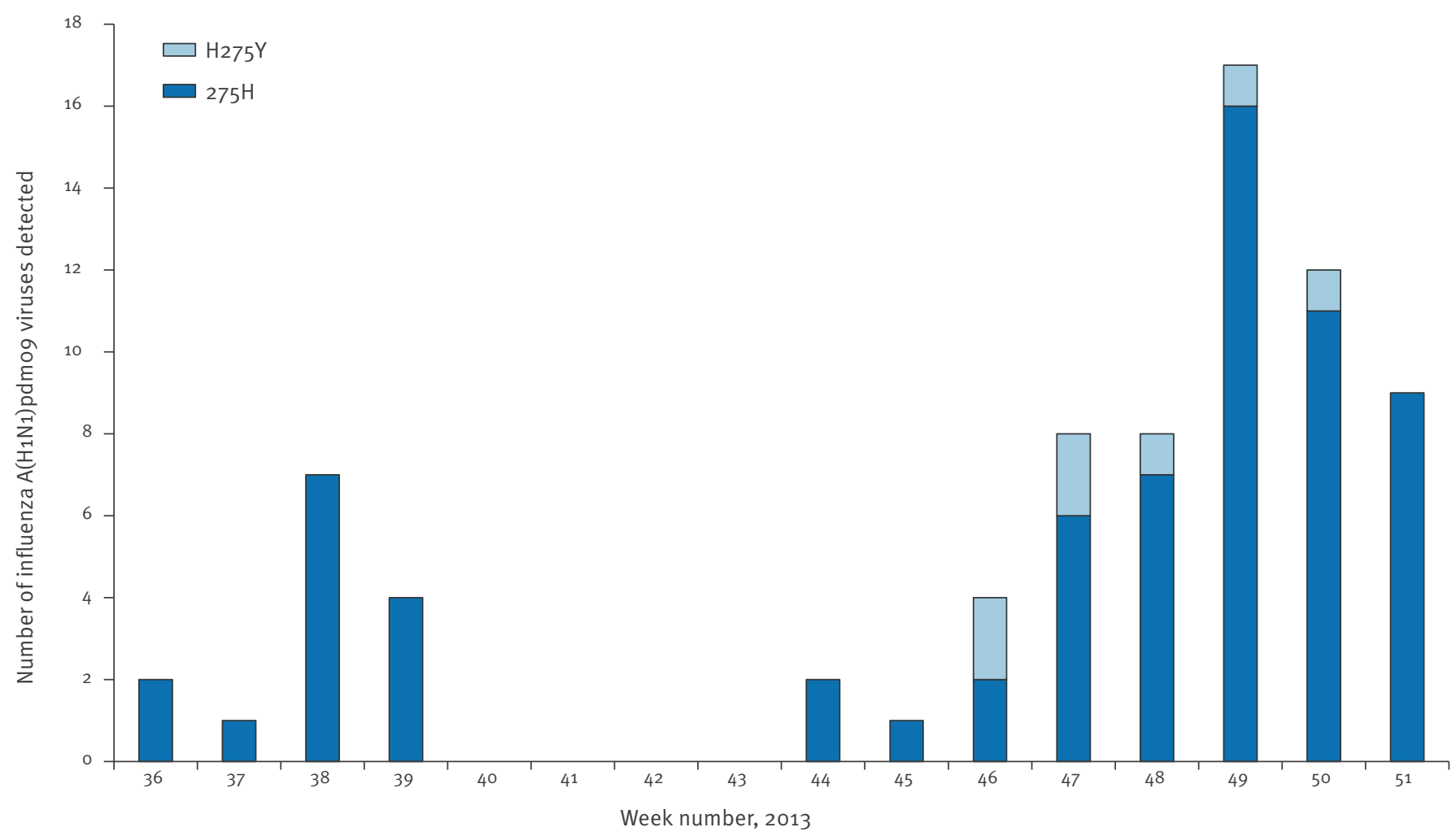

Weekly reports of influenza $\mathrm{A}\left(\mathrm{H}_{1} \mathrm{~N}_{1}\right)$ pdmog virus isolation/detection by local public health institutes under the National Epidemiological Surveillance of Infectious Diseases.

${ }^{a}$ Week 36 started on 2 September 2013.

Organization criteria based on the fold change of $\mathrm{IC}_{50}$ values compared with reference $\mathrm{IC}_{50}$ values were applied [4]. For influenza A viruses, normal ( $\$ 10$-fold increase), reduced (10-100-fold increase) or highly reduced ( $>100$-fold increase) inhibition were defined. All five $\mathrm{H}_{275} \mathrm{Y}$ mutant viruses showed more than 600- and 170 -fold increased $I C_{50}$ values to oseltamivir and peramivir, respectively, compared with the $275 \mathrm{H}$ reference virus. However, the $\mathrm{IC}_{50}$ values of the $\mathrm{H}_{275} \mathrm{Y}$ mutants to zanamivir and laninamivir were comparable to those of the $275 \mathrm{H}$ reference virus. These results indicate that the five $\mathrm{H}_{275} \mathrm{Y}$ mutant viruses tested exhibit highly reduced inhibition by oseltamivir and peramivir, but remain fully susceptible to zanamivir and laninamivir.

In the United States, the Centers for Disease Control and Prevention reported that 10 (1.3\%) of 768 influenza $\mathrm{A}\left(\mathrm{H}_{1} \mathrm{~N}_{1}\right)$ pdmog viruses were resistant to oseltamivir in the 2013/14 season, as of week 512013 [5]. Five of the 10 resistant viruses were detected in Louisiana and Mississippi (Table 3), suggesting a cluster of resistant viruses. The largest cluster of influenza $A\left(\mathrm{H}_{1} \mathrm{~N}_{1}\right)$ pdmog viruses with the $\mathrm{H}_{275} \mathrm{Y}$ substitution occurred in Newcastle, Australia, in 2011: 29 (15\%) of 191 influenza $\mathrm{A}\left(\mathrm{H}_{1} \mathrm{~N}_{1}\right)$ pdmog viruses possessed the $\mathrm{H}_{275} \mathrm{Y}$ substitution [6].
For comparison with the six $\mathrm{H}_{275} \mathrm{Y}$ mutant viruses detected in Sapporo, HA and NA gene sequences of the $\mathrm{H}_{275} \mathrm{Y}$ mutant viruses isolated in the United States and Australia were downloaded from the Epiflu database of the Global Initiative on Sharing All Influenza Data (GISAID) (Table 3). The HA and NA genes of the

\section{TABLE 1}

Influenza $\mathrm{A}(\mathrm{H} 1 \mathrm{~N} 1) \mathrm{pdm} 09$ viruses with $\mathrm{H} 275 \mathrm{Y}$ substitution detected in Sapporo, Japan, November-December 2013 $(\mathrm{n}=6)$

\begin{tabular}{|l|l|c|}
\hline GISAID isolate ID & \multicolumn{1}{|c|}{ Isolate name } & $\begin{array}{c}\text { Collection } \\
\text { date }\end{array}$ \\
\hline EPI_ISL_152910 & A/Sapporo/107/2013 & $2013-11-15$ \\
\hline EPI_ISL_152927 & A/Sapporo/114/2013 & $2013-11-24$ \\
\hline EPI_ISL_152931 & A/Sapporo/TH1/2013 & $2013-11-25$ \\
\hline EPI_ISL_152928 & A/Sapporo/116/2013 & $2013-11-26$ \\
\hline EPI_ISL_152929 & A/Sapporo/119/2013 & $2013-12-07$ \\
\hline EPI_ISL_152930 & A/Sapporo/120/2013 & $2013-12-09$ \\
\hline
\end{tabular}

GISAID: Global Initiative on Sharing All Influenza Data. 


\section{FIGURE 2}

Phylogenetic analysis of the neuraminidase gene of the six H275Y mutant influenza A(H1N1)pdm09 viruses isolated in Sapporo, Japan, and the United States in 2013 and in Australia in 2011

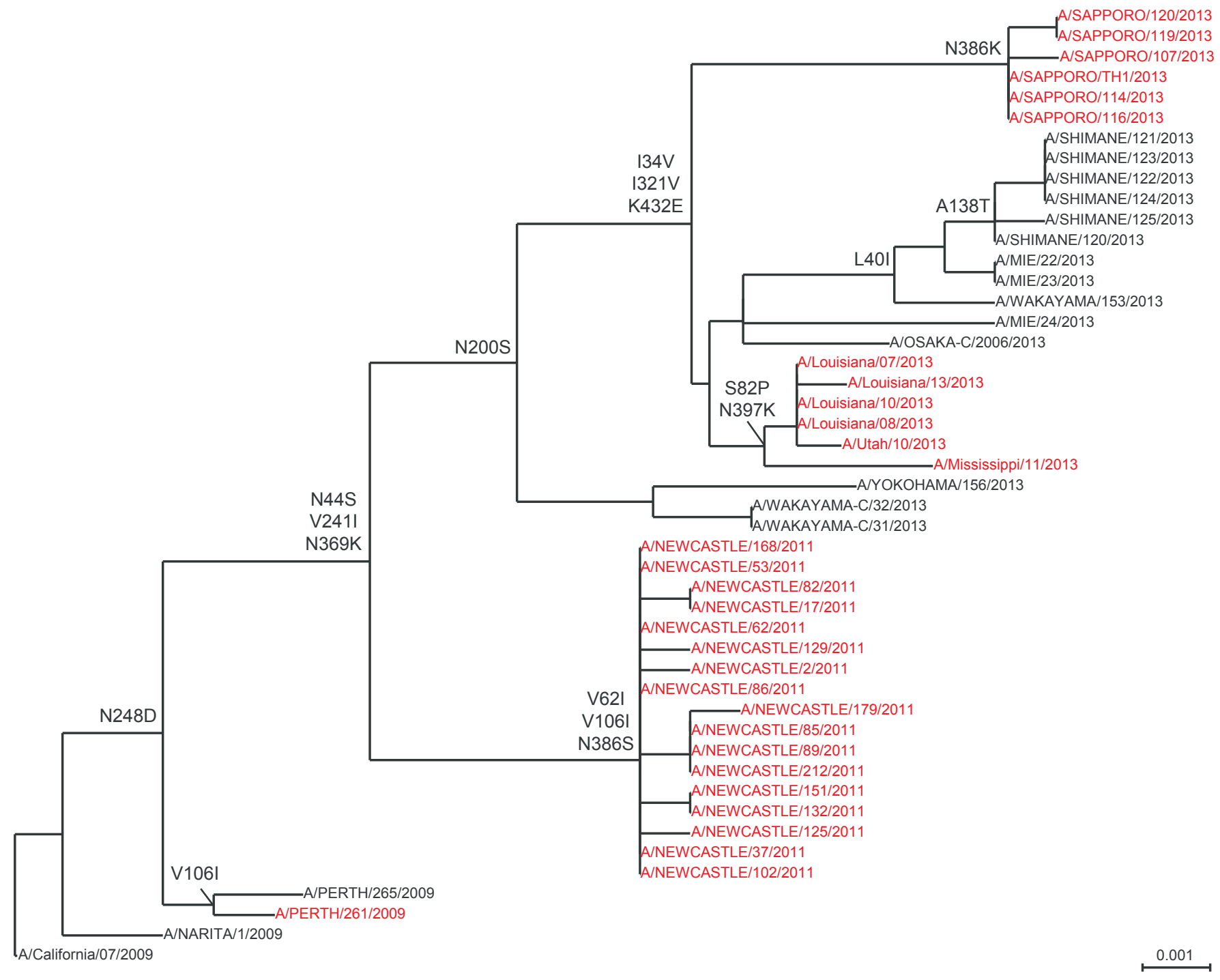

Multiple alignment was constructed using the CLUSTAL W algorithm. The tree was constructed using the neighbor-joining method with bootstrap analyses of 1,000 replicates in CLUSTAL W. The H275Y mutant viruses are shown in red. Amino acid substitutions relative to the A/ California/07/2009 virus are shown on the left of the nodes. The gene sequences of the H275Y mutant viruses isolated in the United States and Australia were downloaded from the EpiFlu database of the Global Initiative on Sharing All Influenza Data (GISAID).

\section{TABLE 2}

Susceptibility of five influenza A(H1N1)pdm09 viruses with H275Y substitution to neuraminidase inhibitors, detected in Sapporo, Japan, November-December 2013

\begin{tabular}{|c|c|c|c|c|c|}
\hline \multirow{2}{*}{ Isolate name } & \multirow{2}{*}{$\begin{array}{c}\text { NA } \\
\text { substitution }\end{array}$} & \multicolumn{4}{|c|}{$\mathrm{IC}_{50}(\mathrm{nM})$} \\
\hline & & Oseltamivir & Peramivir & Zanamivir & Laninamivir \\
\hline A/SAPPORO/107/2013 & $\mathrm{H} 275 \mathrm{Y}$ & 240.60 & 35.28 & 0.50 & 0.81 \\
\hline A/SAPPORO/114/2013 & $\mathrm{H} 275 \mathrm{Y}$ & 193.05 & 22.86 & 0.50 & 0.63 \\
\hline A/SAPPORO/116/2013 & $\mathrm{H} 275 \mathrm{Y}$ & 257.10 & 23.97 & 0.43 & 0.53 \\
\hline A/SAPPORO/119/2013 & $\mathrm{H} 275 \mathrm{Y}$ & 189.25 & 23.19 & 0.43 & 0.58 \\
\hline A/SAPPORO/120/2013 & $\mathrm{H} 275 \mathrm{Y}$ & 192.44 & 22.35 & 0.45 & 0.54 \\
\hline \multicolumn{6}{|l|}{ Reference isolates ${ }^{a}$} \\
\hline A/PERTH/261/2009 & $\mathrm{H} 275 \mathrm{Y}$ & 257.88 & 34.30 & 0.30 & 0.35 \\
\hline A/PERTH/265/2009 & $275 \mathrm{H}$ & 0.31 & 0.13 & 0.30 & 0.29 \\
\hline
\end{tabular}

$\mathrm{IC}_{50}$ : drug concentrations required to inhibit NA activity by $50 \%$; NA: neuraminidase.

a $\mathrm{A} / \mathrm{PERTH} / 261 / 2009$ is the $\mathrm{H}_{275} \mathrm{Y}$ reference virus. A/PERTH/265/2009 is the $275 \mathrm{H}$ wild-type influenza $\mathrm{A}\left(\mathrm{H}_{1} \mathrm{~N}_{1}\right)$ pdmog reference virus. 


\section{TABLE 3}

Accession numbers of the H275Y mutant influenza A(H1N1)pdm09 viruses detected in the United States in 2013 and in Australia in 2011

\begin{tabular}{|c|c|c|c|c|}
\hline GISAID Isolate ID & Isolate name & $\begin{array}{l}\text { Collection } \\
\text { date }\end{array}$ & Originating laboratory & Submitting laboratory \\
\hline EPI_ISL_150042 & A/Louisiana/07/2013 & 2013-10-07 & $\begin{array}{l}\text { Louisiana Department } \\
\text { of Health and Hospitals }\end{array}$ & $\begin{array}{l}\text { Centers for Disease Control and } \\
\text { Prevention }\end{array}$ \\
\hline EPI_ISL_150043 & A/Louisiana/08/2013 & 2013-10-09 & $\begin{array}{l}\text { Louisiana Department } \\
\text { of Health and Hospitals }\end{array}$ & $\begin{array}{l}\text { Centers for Disease Control and } \\
\text { Prevention }\end{array}$ \\
\hline EPI_ISL_150298 & A/Louisiana/10/2013 & $2013-10-21$ & $\begin{array}{l}\text { Louisiana Department } \\
\text { of Health and Hospitals }\end{array}$ & $\begin{array}{l}\text { Centers for Disease Control and } \\
\text { Prevention }\end{array}$ \\
\hline EPI_ISL_151839 & A/Mississippi/11/2013 & 2013-11-04 & $\begin{array}{l}\text { Mississippi Public Health } \\
\text { Laboratory }\end{array}$ & $\begin{array}{l}\text { Centers for Disease Control and } \\
\text { Prevention }\end{array}$ \\
\hline EPI_ISL_151838 & A/Louisiana/13/2013 & $2013-11-11$ & $\begin{array}{l}\text { Louisiana Department of Health and } \\
\text { Hospitals }\end{array}$ & $\begin{array}{l}\text { Centers for Disease Control and } \\
\text { Prevention }\end{array}$ \\
\hline EPI_ISL_95596 & A/Newcastle/2/2011 & 2011-05-31 & $\begin{array}{l}\text { John Hunter Hospital, Virology Unit, } \\
\text { Clinical Microbiology }\end{array}$ & $\begin{array}{l}\text { WHO Collaborating Centre for Reference } \\
\text { and Research on Influenza }\end{array}$ \\
\hline EPI_ISL_95595 & A/Newcastle/17/2011 & 2011-06-20 & $\begin{array}{l}\text { John Hunter Hospital, Virology Unit, } \\
\text { Clinical Microbiology }\end{array}$ & $\begin{array}{l}\text { WHO Collaborating Centre for Reference } \\
\text { and Research on Influenza }\end{array}$ \\
\hline EPI_ISL_95597 & A/Newcastle/37/2011 & 2011-06-23 & $\begin{array}{l}\text { John Hunter Hospital, Virology Unit, } \\
\text { Clinical Microbiology }\end{array}$ & $\begin{array}{l}\text { WHO Collaborating Centre for Reference } \\
\text { and Research on Influenza }\end{array}$ \\
\hline EPI_ISL_101526 & A/Newcastle/125/2011 & 2011-06-30 & $\begin{array}{l}\text { John Hunter Hospital, Virology Unit, } \\
\text { Clinical Microbiology }\end{array}$ & $\begin{array}{l}\text { WHO Collaborating Centre for Reference } \\
\text { and Research on Influenza }\end{array}$ \\
\hline EPI_ISL_95598 & A/Newcastle/53/2011 & 2011-06-30 & $\begin{array}{l}\text { John Hunter Hospital, Virology Unit, } \\
\text { Clinical Microbiology }\end{array}$ & $\begin{array}{l}\text { WHO Collaborating Centre for Reference } \\
\text { and Research on Influenza }\end{array}$ \\
\hline EPI_ISL_95600 & A/Newcastle/82/2011 & 2011-07-01 & $\begin{array}{l}\text { John Hunter Hospital, Virology Unit, } \\
\text { Clinical Microbiology }\end{array}$ & $\begin{array}{l}\text { WHO Collaborating Centre for Reference } \\
\text { and Research on Influenza }\end{array}$ \\
\hline EPI_ISL_95599 & A/Newcastle/62/2011 & 2011-07-01 & $\begin{array}{l}\text { John Hunter Hospital, Virology Unit, } \\
\text { Clinical Microbiology }\end{array}$ & $\begin{array}{l}\text { WHO Collaborating Centre for Reference } \\
\text { and Research on Influenza }\end{array}$ \\
\hline EPI_ISL_101511 & A/Newcastle/86/2011 & 2011-07-02 & $\begin{array}{l}\text { John Hunter Hospital, Virology Unit, } \\
\text { Clinical Microbiology }\end{array}$ & $\begin{array}{l}\text { WHO Collaborating Centre for Reference } \\
\text { and Research on Influenza }\end{array}$ \\
\hline EPI_ISL_101527 & A/Newcastle/129/2011 & 2011-07-03 & $\begin{array}{l}\text { John Hunter Hospital, Virology Unit, } \\
\text { Clinical Microbiology }\end{array}$ & $\begin{array}{l}\text { WHO Collaborating Centre for Reference } \\
\text { and Research on Influenza }\end{array}$ \\
\hline EPI_ISL_95602 & A/Newcastle/89/2011 & 2011-07-04 & $\begin{array}{l}\text { John Hunter Hospital, Virology Unit, } \\
\text { Clinical Microbiology }\end{array}$ & $\begin{array}{l}\text { WHO Collaborating Centre for Reference } \\
\text { and Research on Influenza }\end{array}$ \\
\hline EPI_ISL_95601 & A/Newcastle/85/2011 & 2011-07-04 & $\begin{array}{l}\text { John Hunter Hospital, Virology Unit, } \\
\text { Clinical Microbiology }\end{array}$ & $\begin{array}{l}\text { WHO Collaborating Centre for Reference } \\
\text { and Research on Influenza }\end{array}$ \\
\hline EPI_ISL_101525 & A/Newcastle/102/2011 & 2011-07-05 & $\begin{array}{l}\text { John Hunter Hospital, Virology Unit, } \\
\text { Clinical Microbiology }\end{array}$ & $\begin{array}{l}\text { WHO Collaborating Centre for Reference } \\
\text { and Research on Influenza }\end{array}$ \\
\hline EPI_ISL_95593 & A/Newcastle/132/2011 & 2011-07-10 & $\begin{array}{l}\text { John Hunter Hospital, Virology Unit, } \\
\text { Clinical Microbiology }\end{array}$ & $\begin{array}{l}\text { WHO Collaborating Centre for Reference } \\
\text { and Research on Influenza }\end{array}$ \\
\hline EPI_ISL_95594 & A/Newcastle/151/2011 & 2011-07-11 & $\begin{array}{l}\text { John Hunter Hospital, Virology Unit, } \\
\text { Clinical Microbiology }\end{array}$ & $\begin{array}{l}\text { WHO Collaborating Centre for Reference } \\
\text { and Research on Influenza }\end{array}$ \\
\hline EPI_ISL_101540 & A/Newcastle/168/2011 & $2011-07-12$ & $\begin{array}{l}\text { John Hunter Hospital, Virology Unit, } \\
\text { Clinical Microbiology }\end{array}$ & $\begin{array}{l}\text { WHO Collaborating Centre for Reference } \\
\text { and Research on Influenza }\end{array}$ \\
\hline EPI_ISL_101564 & A/Newcastle/179/2011 & 2011-07-15 & $\begin{array}{l}\text { John Hunter Hospital, Virology Unit, } \\
\text { Clinical Microbiology }\end{array}$ & $\begin{array}{l}\text { WHO Collaborating Centre for Reference } \\
\text { and Research on Influenza }\end{array}$ \\
\hline EPI_ISL_101565 & A/Newcastle/212/2011 & 2011-08-02 & $\begin{array}{l}\text { John Hunter Hospital, Virology Unit, } \\
\text { Clinical Microbiology }\end{array}$ & $\begin{array}{l}\text { WHO Collaborating Centre for Reference } \\
\text { and Research on Influenza }\end{array}$ \\
\hline
\end{tabular}

GISAID: Global Initiative on Sharing All Influenza Data.

H275Y mutant viruses in Sapporo, the United States and Australia were distinct from one another (Table 4).

\section{Discussion}

During the 2007/08 influenza season, an oseltamivirresistant former seasonal influenza $\mathrm{A}\left(\mathrm{H}_{1} \mathrm{~N}_{1}\right)$ virus emerged in Europe and became the majority of $A\left(\mathrm{H}_{1} \mathrm{~N}_{1}\right)$ viruses within a year [7]. This oseltamivir-resistant
$\mathrm{A}\left(\mathrm{H}_{1} \mathrm{~N}_{1}\right)$ virus possessed the $\mathrm{H}_{275} \mathrm{Y}$ substitution; some additional amino acid substitutions were also reported for the virus that could make the mutant virus biologically stable $[8,9]$. Since the $\mathrm{H}_{275} \mathrm{Y}$ substitution would destabilise the mutant virus, the oseltamivir-resistant $A\left(\mathrm{H}_{1} \mathrm{~N}_{1}\right)$ virus probably acquired the capacity for efficient human-to-human transmission through these stabilising substitutions. 
Characteristic amino acids of H275Y mutant influenza A(H1N1)pdm09 viruses isolated in Sapporo, Japan, in 2013 (n=6) and the United States in 2013 and in Australia in 2011

\begin{tabular}{|c|c|c|c|c|c|c|c|c|c|c|c|}
\hline \multirow{2}{*}{ HA gene of isolated viruses } & \multicolumn{11}{|c|}{ Amino acid position } \\
\hline & 15 & 97 & 112 & 143 & 163 & 197 & 222 & 223 & 256 & 283 & 499 \\
\hline $\begin{array}{l}\text { Reference virus } \\
\text { A/PERTH/265/2009 }\end{array}$ & $\mathrm{T}$ & D & E & $\mathrm{S}$ & K & A & D & Q & $A$ & K & E \\
\hline Sapporo, Japan, 2013 & $\mathrm{~S}$ & $\mathrm{~N}$ & $\mathrm{E}$ & $S$ & Q & A & D & Q & $\mathrm{T}$ & D & K \\
\hline United States, 2013 & $T$ & $\mathrm{~N}$ & $E$ & $\mathrm{~S}$ & $Q$ & $A$ & D & $Q$ & $T$ & $E$ & K \\
\hline Australia, 2011 & $T$ & D & K & G & K & $T$ & D & Q & $A$ & K & $\mathrm{E}$ \\
\hline
\end{tabular}

\begin{tabular}{|c|c|c|c|c|c|c|c|c|c|c|c|c|}
\hline \multirow{2}{*}{ NA gene of isolated viruses } & \multicolumn{12}{|c|}{ Amino acid position } \\
\hline & 34 & 62 & 82 & 106 & 200 & 241 & 275 & 321 & 369 & 386 & 397 & 432 \\
\hline $\begin{array}{l}\text { Reference virus } \\
\text { A/PERTH/265/2009 }\end{array}$ & I & V & S & I & $\mathrm{N}$ & V & $\mathrm{H}$ & 1 & $\mathrm{~N}$ & $\mathrm{~N}$ & $\mathrm{~N}$ & K \\
\hline Sapporo, Japan, 2013 & V & v & $\mathrm{S}$ & $\mathrm{V}$ & $\mathrm{S}$ & 1 & $\mathrm{Y}$ & V & $\mathrm{K}$ & K & $\mathrm{N}$ & $\mathrm{E}$ \\
\hline United States, 2013 & V & V & $\mathrm{P}$ & $\mathrm{v}$ & $\mathrm{S}$ & 1 & $\mathrm{Y}$ & $\mathrm{V}$ & $\mathrm{K}$ & $\mathrm{N}$ & K & $\mathrm{E}$ \\
\hline Australia, 2011 & I & 1 & S & I & $\mathrm{N}$ & I & Y & 1 & K & S & $\mathrm{N}$ & $\mathrm{K}$ \\
\hline
\end{tabular}

HA: haemagglutinin; NA: neuraminidase.

In the case of $\mathrm{H}_{2} 75 \mathrm{Y}$ mutants of influenza $\mathrm{A}\left(\mathrm{H}_{1} \mathrm{~N}_{1}\right)$ pdmo9 viruses, three substitutions (V241l, N369K and $\mathrm{N}_{3} 86 \mathrm{~S}$ ) in the NA protein may offset the destabilising effect of the $\mathrm{H}_{275} \mathrm{Y}$ mutation [6]. The influenza $\mathrm{A}\left(\mathrm{H}_{1} \mathrm{~N}_{1}\right)$ pdmog virus that appeared in 2009 as a pandemic virus had none of these stabilising substitutions, whereas the $\mathrm{A}\left(\mathrm{H}_{1} \mathrm{~N}_{1}\right)$ pdmog viruses that have been circulating since 2011 to date have acquired two of the three substitutions. The $\mathrm{H}_{275} \mathrm{Y}$ mutant viruses detected in a community cluster in 2011 in Newcastle, Australia, contained these three substitutions [6]. Furthermore, the same substitutions were detected in $\mathrm{H}_{275} \mathrm{Y}$ mutant viruses isolated from Dutch travellers returning from Spain in 2012 [10]. In our study, all $\mathrm{H} 275 \mathrm{Y}$ mutant viruses detected in Sapporo possessed V241l, N369K and N386K substitutions (Table 4); H275Y mutant viruses found in the United States possessed only V241l and $\mathrm{N}_{369 \mathrm{~K}}$ substitutions (Table 4). Before the 2013/14 influenza season, we had not detected any $\mathrm{H}_{275} \mathrm{Y}$ mutant viruses with $\mathrm{V}_{241}$, N369K and N386K substitutions in Japan. The effect of the N386K substitution - at the same position but with an amino acid residue that differs from $\mathrm{N}_{3} 86 \mathrm{~S}$ previously reported for $\mathrm{H} 275 \mathrm{Y}$ mutant viruses - remains to be clarified.

D222G and Q223R substitutions in the HA protein of influenza $A\left(\mathrm{H}_{1} \mathrm{~N}_{1}\right)$ pdmog viruses are known to cause a switch in receptor-binding preference from human-type $\mathrm{a}-2,6$ to avian-type a-2,3 sialic acid [11-13]. All $\mathrm{H} 275 \mathrm{Y}$ mutant viruses detected in Sapporo and the United States in the $2013 / 14$ season did not contain these substitutions that would be associated with increased pathogenicity (Table 4 ). The reason why the patient in her late 30 in Sapporo developed severe pneumonia has yet to be studied.

It has been shown that oseltamivir-resistant influenza $A\left(\mathrm{H}_{1} \mathrm{~N}_{1}\right)$ virus infection reduced the effectiveness of oseltamivir and this tendency was more apparent in children o to 6 years old [14-16]. Among patients from whom oseltamivir- and peramivir-resistant $A\left(\mathrm{H}_{1} \mathrm{~N}_{1}\right)$ pdmog viruses have been detected in Japan, the percentage with no known exposure to NA inhibitors has increased significantly, from $16 \%$ during the pandemic period to $44 \%$ during the post-pandemic period [2]. These observations may suggest that human-to-human transmission with $\mathrm{H}_{275} \mathrm{Y}$ mutant viruses has increased gradually in the post-pandemic period. Consequently, surveillance of antiviral-resistant influenza viruses should be continued and strengthened, particularly for the choice of antiviral drugs.

\section{Acknowledgments}

We acknowledge the authors, originating and submitting laboratories of the sequences from GISAID's EpiFlu Database that are used in this article (see Tables 1 and 3). All submitters of data may be contacted directly via the GISAID website www.gisaid.org

This study was supported by Grants-in-Aid for Emerging and Reemerging Infectious Diseases from the Ministry of Health, Labour and Welfare, Japan.

Conflict of interest

None declared. 


\section{Authors' contributions}

Designed the analyses: ET, AO, HN, TO, MT. Analysed and interpreted data: ET, ME, RI, MM, AO, HN, TO, MT. Drafted the article: ET. Revised the article: TO, MT.

\section{References}

1. Nakauchi M, Ujike M, Obuchi M, Takashita E, Takayama I, Ejima $\mathrm{M}$, et al. Rapid discrimination of oseltamivir-resistant $275 \mathrm{Y}$ and -susceptible $275 \mathrm{H}$ substitutions in the neuraminidase gene of pandemic influenza A/H1N1 2009 virus by duplex one-step RTPCR assay. J Med Virol. 2011;83(7):1121-7.

http://dx.doi.org/10.1002/jmv.22101

PMid:21567417

2. Takashita E, Fujisaki S, Kishida N, Xu H, Imai M, Tashiro M, et al. Characterization of neuraminidase inhibitor-resistant influenza $\mathrm{A}\left(\mathrm{H}_{1} \mathrm{~N}_{1}\right)$ pdmog viruses isolated in four seasons during pandemic and post-pandemic periods in Japan. Influenza Other Respir Viruses. 2013;7(6):1390-9. http://dx.doi.org/10.1111/irv.12132 PMid:23745712

3. World Health Organization (WHO). Laboratory methodologies for testing the antiviral susceptibility of influenza viruses: Reference viruses for validation and controls. Updated November 2012. Geneva: WHO. [Accessed 9 Jan 2014]. Available from: http://www.who.int/influenza/gisrs laboratory/antiviral_susceptibility/referenceviruses/en/index. html

4. Meetings of the WHO working group on surveillance of influenza antiviral susceptibility - Geneva, November 2011 and June 2012. Wkly Epidemiol Rec. 2012;87(39):369-74. PMid:23061103

5. United States Centers for Disease Control and Prevention (CDC). 2013-2014 influenza season week 51 ending December 21, 2013. FluView. Updated 27 December 2013. Atlanta, GA: CDC. [Accessed 29 Dec 2013]. Available from: http://www.cdc. gov/flu/weekly/

6. Hurt AC, Hardie K, Wilson NJ, Deng YM, Osbourn M, Leang SK, et al. Characteristics of a widespread community cluster of $\mathrm{H}_{275} \mathrm{Y}$ oseltamivir-resistant $\mathrm{A}\left(\mathrm{H}_{1} \mathrm{~N}_{1}\right)$ pdmog influenza in Australia. J Infect Dis. 2012;206(2):148-57. http://dx.doi.org/10.1093/infdis/jis337 PMid:22561367 PMCid:PMC3379839

7. Lackenby A, Hungnes O, Dudman SG, Meijer A, Paget WJ, Hay AJ, et al. Emergence of resistance to oseltamivir among influenza $A\left(\mathrm{H}_{1} \mathrm{~N}_{1}\right)$ viruses in Europe. Euro Surveill. 2008;13(5):pii=8026. Available from: http://www. eurosurveillance.org/ViewArticle.aspx?Articleld=8026 PMid:18445375

8. Bloom JD, Gong LI, Baltimore D. Permissive secondary mutations enable the evolution of influenza oseltamivir resistance. Science. 2010; 328(5983):1272-5. http://dx.doi.org/10.1126/science.1187816 PMid:20522774 PMCid:PMC2913718

9. Ginting TE, Shinya K, Kyan Y, Makino A, Matsumoto N, Kaneda $\mathrm{S}$, et al. Amino acid changes in hemagglutinin contribute to the replication of oseltamivir-resistant $\mathrm{H}_{1} \mathrm{~N}_{1}$ influenza viruses. J Virol. 2012;86(1):121-7.

http://dx.doi.org/10.1128/JVI.06085-11

PMid:22013054 PMCid:PMC3255889

10. Meijer A, Jonges $M$, van Beek $P$, Swaan $C M$, Osterhaus AD, Daniels RS, et al. Oseltamivir-resistant influenza $A\left(\mathrm{H}_{1} \mathrm{~N}_{1}\right)$ pdmog virus in Dutch travellers returning from Spain, August 2012. Euro Surveill. 2012;17(36):pii=20266. Available from: http://www.eurosurveillance.org/ViewArticle. aspx?Articleld $=20266$ PMid:22971326

11. Chutinimitkul S, Herfst $S$, Steel I, Lowen AC, Ye J, van Rie $\mathrm{D}$, et al. Virulence-associated substitution $\mathrm{D} 222 \mathrm{G}$ in the hemagglutinin of 2009 pandemic influenza $A\left(\mathrm{H}_{1} \mathrm{~N}_{1}\right)$ virus affects receptor binding. J Virol. 2010;84(22):11802-13. http://dx.doi.org/10.1128/JVI.01136-10 PMid:20844044 PMCid:PMC2977876

12. Liu Y, Childs RA, Matrosovich T, Wharton S, Palma AS, Chai W, et al. Altered receptor specificity and cell tropism of D222G hemagglutinin mutants isolated from fatal cases of pandemic $A\left(H_{1} N_{1}\right) 2009$ influenza virus. J Virol. 2010;84(22):12069-74. http://dx.doi.org/10.1128/JVI.01639-10 PMid:20826688 PMCid:PMC2977873

13. Zhang Y, Zhang Q, Gao Y, He X, Kong H, Jiang Y, et al. Key molecular factors in hemagglutinin and $\mathrm{PB} 2$ contribute to efficient transmission of the $2009 \mathrm{H}_{1} \mathrm{~N}_{1}$ pandemic influenza virus. J Virol. 2012;86(18):9666-74.
http://dx.doi.org/10.1128/JVI.00958-12 PMid:22740390 PMCid:PMC3446561

14. Kawai N, Ikematsu H, Iwaki N, Kondou K, Hirotsu N, Kawashima $\mathrm{T}$, et al. Clinical effectiveness of oseltamivir for influenza $\mathrm{A}\left(\mathrm{H}_{1} \mathrm{~N}_{1}\right)$ virus with $\mathrm{H}_{2} 74 \mathrm{Y}$ neuraminidase mutation. J Infect. 2009;59(3):207-12.

http://dx.doi.org/10.1016/j.jinf.2009.07.002

PMid:19619898

15. Kawai N, Ikematsu H, Hirotsu N, Maeda T, Kawashima T, Tanaka O, et al. Clinical effectiveness of oseltamivir and zanamivir for treatment of influenza A virus subtype $\mathrm{H}_{1} \mathrm{~N}_{1}$ with the $\mathrm{H}_{274} \mathrm{Y}$ mutation: a Japanese, multicenter study of the 2007-2008 and 2008-2009 influenza seasons. Clin Infect Dis. 2009;49(12):1828-35.

http://dx.doi.org/10.1086/648424

PMid:19911968

16. Saito R, Sato I, Suzuki Y, Baranovich T, Matsuda R, Ishitani N, et al. Reduced effectiveness of oseltamivir in children infected with oseltamivir-resistant influenza $A\left(\mathrm{H}_{1} \mathrm{~N}_{1}\right)$ viruses with His275Tyr mutation. Pediatr Infect Dis J. 2010;29(10):898-904. http://dx.doi.org/10.1097/INF.obo13e3181de9d24 PMid:20442686 